\title{
Genentech's Cabilly victory
}

A four-year battle over one of the most ubiquitous patents in biotech ended with the US Patent and Trademark Office (USPTO) coming down on Genentech's side. The decision, reached in February, leaves Genentech's Cabilly II patent stronger than ever, and valid through 2018. The patent covers a fundamental method for making therapeutic recombinant antibodies, and nearly anyone selling —or planning to sell-a product made with this method must pay Genentech's often hefty license fees. "If you're going to make an antibody, you're going to have to deal with Genentech," says Ken Clark, a partner at Wilson Sonsini Goodrich \& Rosati in Palo Alto.

The S. San Francisco-based biotech, now fully owned by Swiss drugmaker Roche after agreeing in March on a buyout price of $\$ 46.8$ billion, has fought off four patent office rejections to Cabilly II since September 2005. The company has also defended the patent in a Supreme Court lawsuit brought by Medlmmune (Nat. Biotechnol. 26, 846, 2008). A quick look at the revenue-and future revenue-from Cabilly II makes clear why Genentech so adamantly pursued the validation of the patent: the royalty revenue far exceeds the legal costs of defending it. In 2008 alone, Cabilly II generated at least $\$ 237$ million for the company. "It's not even close in terms of whether it was worth it for Genentech," says Clark.

The patent office initially rejected Cabilly II on grounds of obvious-type double patenting-the method was not novel but a variant of previous patents including the Cabilly I patent issued in 1989. But Genentech argued that in Cabilly I, to produce a functional immunoglobulin molecule, the host cell is transformed with either an immunoglobulin heavy chain or light chain separately, whereas in Cabilly II, the host cell is inserted with DNA sequences encoding both heavy and light chains. To make this clear, Genentech had to amend 11 of Cabilly II's claims but "in a way that does not affect the commercial importance of the patent," according to Genentech.

The patent office also questioned whether the technology described in Cabilly II would have been obvious to scientists own products, involve the technology. Genentech did not disclose in SEC filings its 2008 licensees, but in the past, it has named Humira (adalimumab), from Abbott Laboratories, Abbott Park, Illinois; Remicade (infliximab), from Centocor of Horsham, Pennsylvania; Erbitux (cetuximab), from New Yorkbased ImClone; and Synagis (palivizumab) from MedImmune of Gaithersburg, Maryland. Royalty revenue from just one of these drugs likely far exceeds the cost of defending the patent, say attorneys. For example, US sales of Humira in 2008 topped $\$ 2.2$ billion. At a 3\% royalty rate, Abbott would have paid Genentech $\$ 66$ million to license Cabilly in 2008 alone. Genentech likely charges its licensees 3-5\% royalty on approved products, according to people familiar with the matter.

The patent office's rigorous reexamination will make Cabilly II harder to invalidate in the future, says Kevin Noonan, a partner at McDonnell Boehnen Hulbert \& Berghoff in Chicago. The claim against Cabilly listed "a ton of references" for why the patent was invalid, he says, all of which the patent office addressed. Licensees are likely stuck with the royalty fees through 2018, say attorneys. "I would guess we're finished" with challenges against Cabilly II, says Stephen Albainy-Jenei, an attorney with Frost Brown Todd in Cincinnati. "You'd have to either find some new killer references or you'd have to say the patent office had made a total mistake with one or two of the references-like they said it was blue when it was actually red."

Emily Waltz

\section{IN their words}

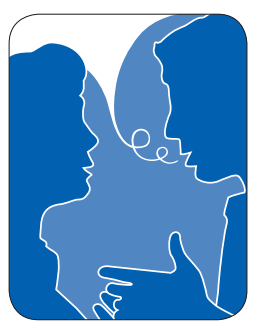

"We are not arriving there with a blueprint of what needs to be done."

Roche Chairman Franz Humer on the challenge of integrating the fiercely independent Genentech, which the Swiss company acquired in March after an eight-month struggle. (WSJ, March 13, 2009)

\begin{abstract}
"Malaria is spread by mosquitoes. I brought some. I'Il let them roam around. There is no reason only poor people should be infected."

Bill Gates opened a mosquito-filled jar onstage at the Technology, Entertainment, Design Conference to spread his malaria message, while reassuring the crowd that the mosquitoes were not infected. (Fox News, Feb 5, 2009)
\end{abstract}

\begin{abstract}
"It makes my head spin trying to keep up with their ever changing arguments for why these terms are justified."

Congressman Henry Waxman, baffled by the brand industry's changing arguments for 12, 14 and even 20 years exclusivity for biogenerics, insists the Hatch-Waxman model should be followed. (Generic Pharmaceutical Association Annual Meeting, February 23-25, 2009)
\end{abstract}

